\title{
New Electrochemical Detection Strategies for lodinated Compounds
}

\author{
LIGIA CHELMEA ${ }^{1}$, FEDERICO DI MODUGNO², IOSIF SAMOTA ${ }^{1}$, ELENA BOBESCU ${ }^{1}$, LAURA FLOROIAN ${ }^{3 *}$, PATRIZIA RESTANI ${ }^{2}$, \\ GABRIELA CIOCA*, SIMONA BUNGAU ${ }^{5}$, MIHAELA BADEA ${ }^{1}$ \\ ${ }^{1}$ Transilvania University of Brasov, Faculty of Medicine, 29 Eroilor Str., 500039, Brasov, Romania \\ 2 Universita Degli Studi di Milano, Faculty of Pharmacology Science, Via Balzaretti, Milan, Italy \\ ${ }^{3}$ Transilvania University of Brasov, Faculty of Electrical Engineering and Computers, 29 Eroilor Str., 500039, Brasov, Romania \\ ${ }^{4}$ Lucian Blaga University of Sibiu, Faculty of Medicine, 10 Victoriei Blvd., 550024, Sibiu, Romania \\ EUniversity of Oradea, Faculty of Medicine and Pharmacy, 29 N. J iga Str., 410028, Oradea, Romania
}

\begin{abstract}
lodine is a micronutrient of high importance for the health and good development of individuals. It is contained in many foods, but it is also part of the chemical component of oceans and soil. Its deficiency is still a problem of humanity, which has a serious repercussion on our health. It is therefore important to have specific, fast and cost effective methods of iodine detection from different samples. This work aims to identify optimal parameters for potassium iodide (KI) detection from different media, to be further applied to real samples: plant extracts, water, biological fluids. Results showed a significant difference in electrochemical results, depending on the $\mathrm{pH}$ values of the mixture and also on the time which influences the compounds stability. Differential pulse voltammetry and cyclic voltammetry using carbon printed sensors, as well as microsensors for redox status or direct iodide detection are important analytical tools which have a wide range of applications in the food, medicine, toxicology and other domains.
\end{abstract}

Keywords: iodide, differential pulse voltammetry, cyclic voltammetry, microsensors, electrochemical detection

lodide is the second element from the halogens group, with low reactivity. The halogen has a diatomic molecule $\left(I_{2}\right)$ and has also only one natural stabile isotope [1]. Physiologically, in the human body, iodide has the higher concentration in thyroid gland, representing $70-80 \%$ of the total iodide, which means almost 120 micrograms of iodide [2]. An important role of iodide is in thyroid hormones synthesis, thyroxin-T4 and triiodothyronine-T3[3].

At the moment it is known that iodine deficiency affects about two billion people and is the leading preventable cause of intellectual disabilities [4]. Consequently, correct intake of iodine is fundamental for the correct function of the thyroid and a normal state of metabolism. Iodide from thyrostatic drugs, plays an important role in the protection of the thyroid gland against certain types of radiopharmaceuticals, because it modifies the kinetics of radioiodine in the thyroid and through this mechanism may also have a radio protective effect. Also a pre-treatment with thyrostatic medication lowers the effective half-life and uptake of radioiodine [5].

It can also be used as food supplement for individuals with low iodine dietary intake and as treatment for hypothyroidism. Although iodine can be helpful, an excessive iodine intake has been associated with adverse reactions such as the increase of thyroid volume [6]. The FDA (Food and Drug Administration) approved the use of potassium iodide (KI) for radiation protection and fixed some indicative daily doses, from $16 \mathrm{mg}$ for infants less than one month old, to $130 \mathrm{mg}$ for adults [7]. Therefore, individuals need a controlled daily uptake of iodine to ensure an optimal level because there are many food products enriched with iodine, buttheir consumption should be balanced [6].

In addition, analytical sensitive iodine determination, was always a problem, especially from natural sources, which contains low concentration of iodine (in food, iodine is in general below $1 \mu \mathrm{g} / \mathrm{g}$ ) [6]. A wide range of analytical

*email; lauraf@unitbv.ro; gabriela.cioca@ulbsibiu.ro methods for iodine determination was developed in order to identify the most sensitive possibility. The majority of electrochemical sensor-based experiments were conducted in cyclic voltammetry [8-11] and performed with diamond electrodes [8], ultrathin gold films [9], poly(3-aminophenylboronic acid) (PAPBA) film electrode [10], modified copper electrode [11], etc. Different methods were carried out with other sensitive electrochemical methods, as potentiostatic polarisation $[12,13]$ or analytical techniques as: ion chromatography [14], spectrophotometry [15-17], X-ray fluorescence spectrometry $[18,19]$, gas chromatography mass spectrometry $[20,21]$, inductively coupled plasma optical emission mass spectrometry (ICP-OES) [18,22], inductively mass spectrometry (ICP-MS) [23-27].

Despite the high sensitivity of the analytical techniques, studies show that those are difficult to reproduce and the complex methods are not cost effective and need special conditions. In addition, iodine determination using electrodes is more feasible for fast and efficient detection of iodine from different samples and also allows accurate quantification of low concentration of substrate. Testing iodide using a carbon-paste electrode is rarely found in literature, especially by analysing redox reaction developed in a large variety of $\mathrm{pH}$ media. Therefore, the aim of this work is to find the efficient electrochemical way to detect iodine from different media, in order to apply the method in the future with real samples as plants extracts, water, food supplements and biological fluids.

\section{Experimental part}

Materials and methods

Reagents

The iodide compound tested was potassium iodide (KI) from Honeyw ell Specialty Chemicals Seelze GmbH, Germany, using a mother solution with a concentration of $0.1 \mathrm{mmol} / \mathrm{L}(0.0166 \mathrm{~g} / \mathrm{L})$. This solution was kept at $4^{\circ} \mathrm{C}$ between determinations, at room temperature during the 
experiments and under dark conditions for the entire period of testing. Different buffers (from 3 to 8) were used, in order to obtain media with different $\mathrm{pH}$ values: citratephosphate buffer ( $p H 3)$; acetate buffer ( $p H 3.6 ; 4 ; 5.8)$; phosphate buffer ( $p H 7 ; 7.4 ; 8)$.

\section{Equipment}

Electrochemical detection was carried out with PalmSens potentiostat/galvanostat and impedance analyser paired with DRP C110 as screen-printed carbon electrode (DropSens, Spain). The analysis was performed using Differential Pulse Voltammetry (DPV), Cyclic Voltammetry (CV), and data quantification used PSTrace 3.2 software. There were also used two portable electrochemical microsensors for the measurement of iodine and redox potential from Jenco Electronics, Ltd. (Texas, USA) type 6230N microcomputer based $\mathrm{pH} / \mathrm{mV} /$ TEMP meter portable meter. All solutions were stirred before each determination with a magnetic stirrer from Velp Scientific.

\section{Methods}

Differential pulse voltammetry, cyclic voltammetry and two techniques using electrochemical microsensors for selective iodide detection were used in these experiments.

\section{Results and discussions}

A. Experiments based on screen-printed carbon electrode A.1.Differential pulse voltammetry (DPV)

The experiments were carried out in five different media of reaction, using a range of concentration from $0.02 \mathrm{mmol} /$ $\mathrm{L}(3.66 \mathrm{mg} / \mathrm{L})$ to $1 \mathrm{mmol} / \mathrm{L}(166 \mathrm{mg} / \mathrm{L})$ and more for some media. The sensor does not require pretesting treatment and was changed after each completed test. Using differential pulse voltammetry (DPV) the electrical signal was registered in a graphic representation. The voltammograms indicated different peaks, which appeared in different ranges for different $p H$ values: $0.9-1$ $\mathrm{V}$ for $\mathrm{pH} 3$ and 5.8; 0.6-0.7 V for $\mathrm{pH} 3.6$ and 4; 0.8-0.9 V for $\mathrm{pH} 7,7.4$ and 8 . The scan rate was $0.01 \mathrm{~V} / \mathrm{s}$. The average data obtained (from three measurements) were indicated in figures 1.a-g.

The best dependence between the height of the peak and the iodide concentration was tested, as a result of the optimization of iodide compound detection using DPV technique,. It was obtained an inverse proportionality ratio between the height of the peak and the iodide concentration in some acid media ( 3 and 3.6), and for $\mathrm{pH}$ medium from 4 to 8 , appeared a proportionality between these measurements (polynomial dependence). Although the influence of the $\mathrm{pH}$ in the reaction is obvious, the iodide signal is significant in all detections, with a good correlation coefficient $\left(R^{2} \approx 1\right)$.

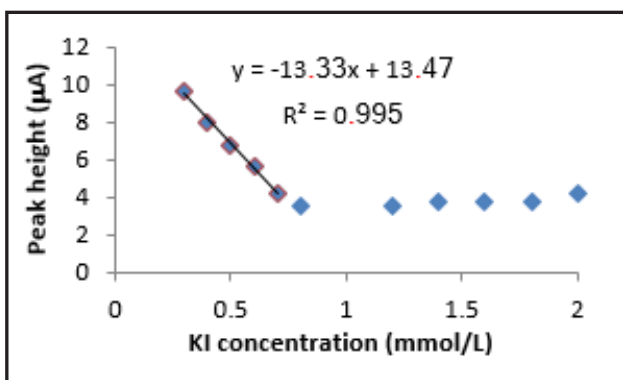

(a)

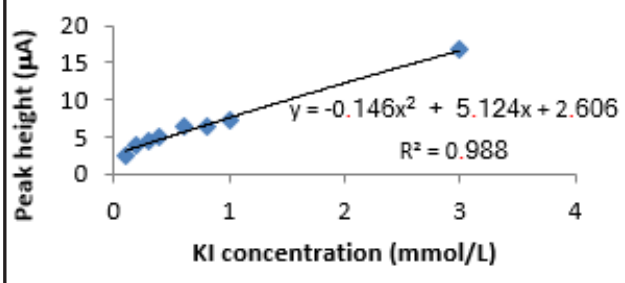

(c)

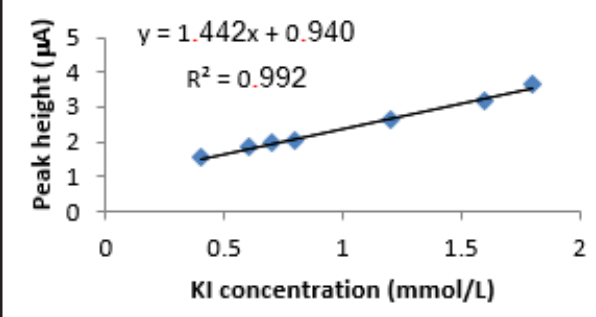

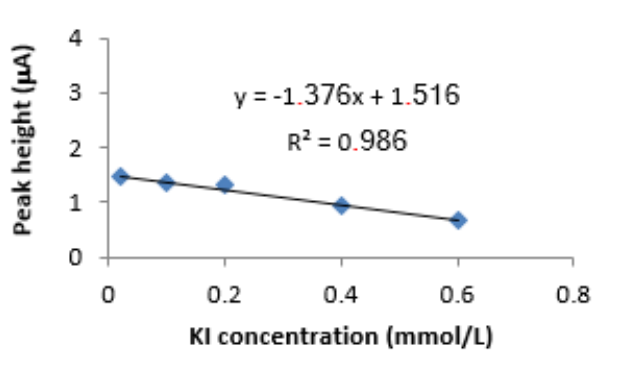

(b)

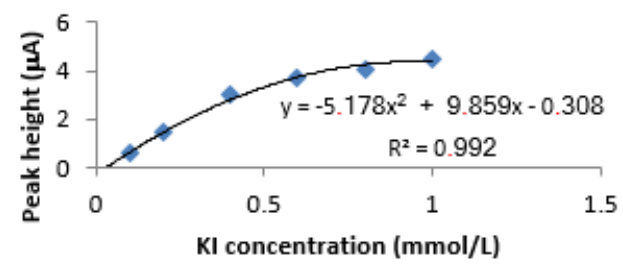

(d)

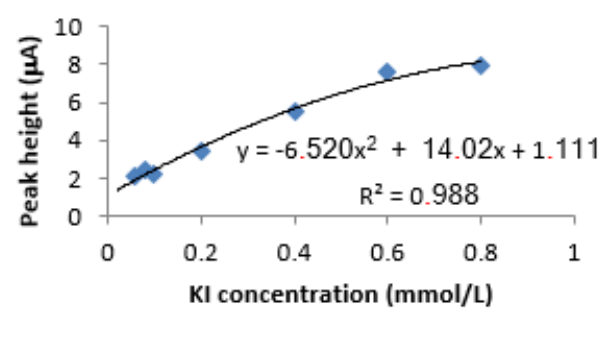

(f)

(e)

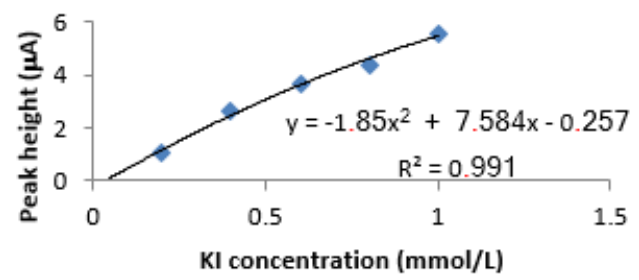

(g)

Fig.1. Voltammograms for iodide detection using DPV method with electrode DRP C110 in (a) citrate-phosphate buffer $\mathrm{pH}$ 3; (b) acetate buffer $\mathrm{pH}$ 3.6; (c) acetate buffer $\mathrm{pH}$ 4; (d) acetate buffer $\mathrm{pH}$ 5.8:(e) phosphate buffer $\mathrm{pH} 7$; 


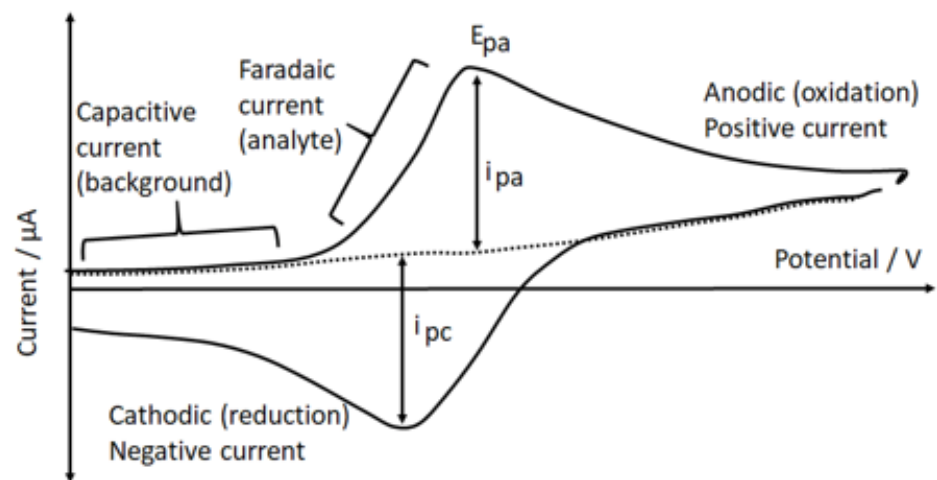

A.2.Cyclic Voltammetry (CV)

The iodine detections using CV technique, a type of potentiodynamic electrochemical measurement (fig.2), were performed at a scan rate of $0.05 \mathrm{~V} / \mathrm{s}$, in the range of potential from $-2.5 \mathrm{~V}$ to $2.0 \mathrm{~V}$, for different $p \mathrm{H}$ values (3.6, 5.8 , and 7.4). The positive and negative peaks heights were measured and data were plotted versus $\mathrm{KI}$ concentrations, for different $\mathrm{pH}$ values (fig. 3).

Analysing figure 3 ., it is obvious the influence of the $\mathrm{pH}$ in the reaction; the iodide signal is strong in all detections, with good linearity.

\section{B. Experiments based on using J enco microelectrodes}

B.1. lodine microelectrode

For the J enco apparatus, using the iodine microelectrode the results were plotted using the recorded potential for each concentration of the working solutions. Graphics display polynomial curves with a positive slope in all media of reaction. The potential ranges have negative values (between -0.1 to $-0.17 \mathrm{~V}$ ) for iodine Jenco microelectrode, as indicated in figure 4.

\section{B.2. Redox microelectrode}

Using the J enco redox microelectrode, the results were plotted according to the potential recorded for each
Fig.2. Cyclic voltammetry indicating the important peak parameters concentration from the working solution (fig. 5). The results obtained are comparable with those from iodine microelectrode, being obtained polynomial curves of electrical signal (potential) versus concentration of electrochemical active compound (KI).

The electrochemical (micro)sensors methods consist in using the properties of electroactivity of potassium iodide $(\mathrm{KI})$, respectively the capture of the electron signal obtained from the electron exchanges. The advantage of these methods is the electroactivity of iodide without adding any pre-treatment steps. Redox reactions were attributed to a two-step redox reaction [28], summarized in the equations below:

$$
\begin{gathered}
3 \mathrm{I}^{-} \rightleftharpoons \mathrm{I}_{3}^{-}+2 \mathrm{e}^{-} \\
2 \mathrm{I}_{3}^{-}
\end{gathered}
$$

It is known that the most important anion is triiodide $\left(\mathrm{I}_{3}\right)$ ). This is the anion determined both quantitatively and qualitatively from the iodinated compounds, by electrochemical methods. By adding potassium iodide (KI) to the reaction, the iodine solubility in water increases and thus increases in direct proportionality the amount of triiodide ion

$$
I_{2}+I^{-} \rightleftharpoons I_{3}^{-}
$$

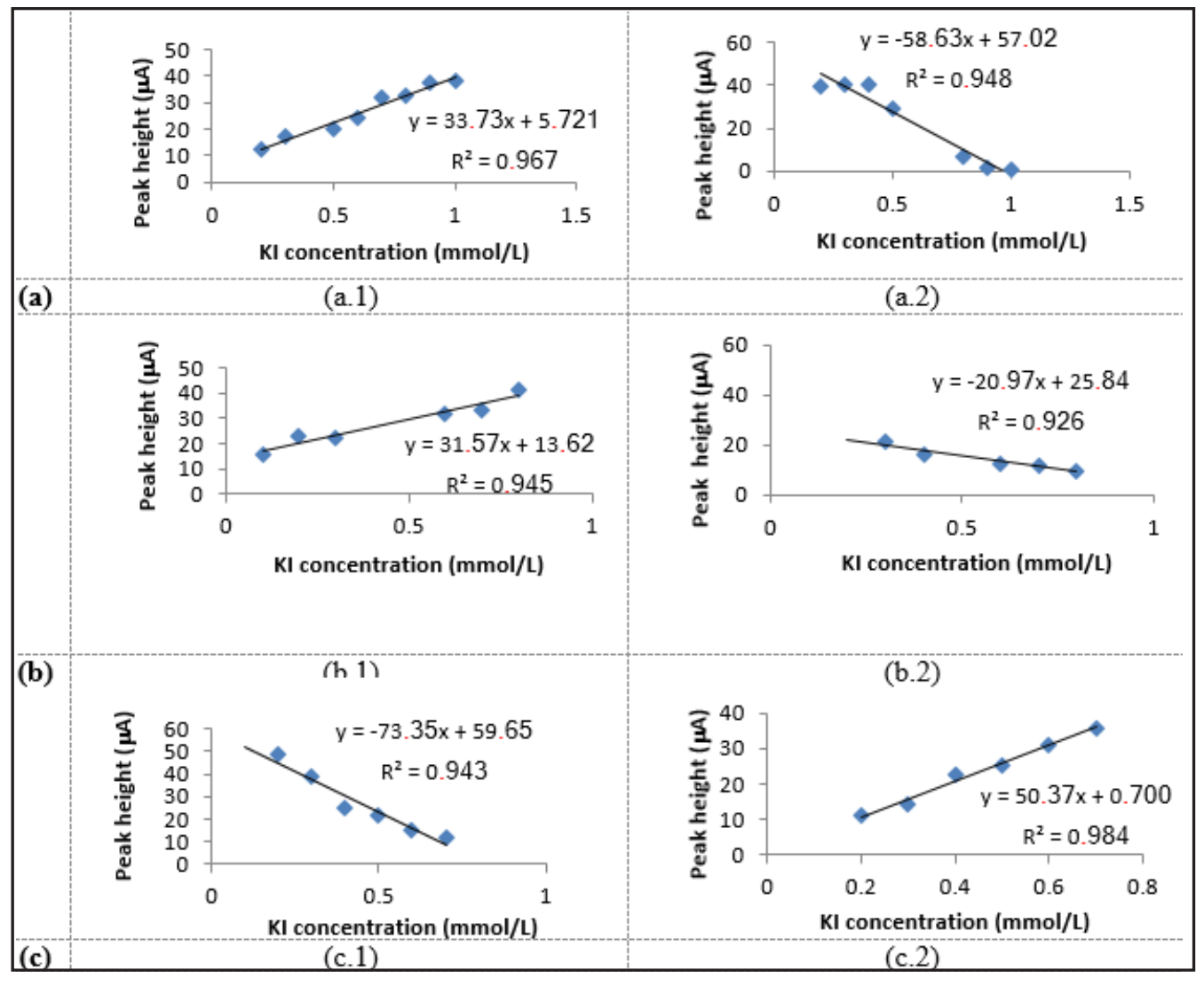

Fig.3. Graphic representation of the height of the peak according to concentration, using CV method with electrode DRP C110 in:

(a) acetate buffer $\mathrm{pH}$ 3.6,

(a.1) oxidation curve and

(a.2) reduction curve;

(b) acetate buffer $\mathrm{pH} 5.8$,

(b.1) oxidation curve and

(b.2) reduction curve;

(c) phosphate buffer $\mathrm{pH} 7.4$,

(c.1) oxidation curve and

(c.2) reduction curve 


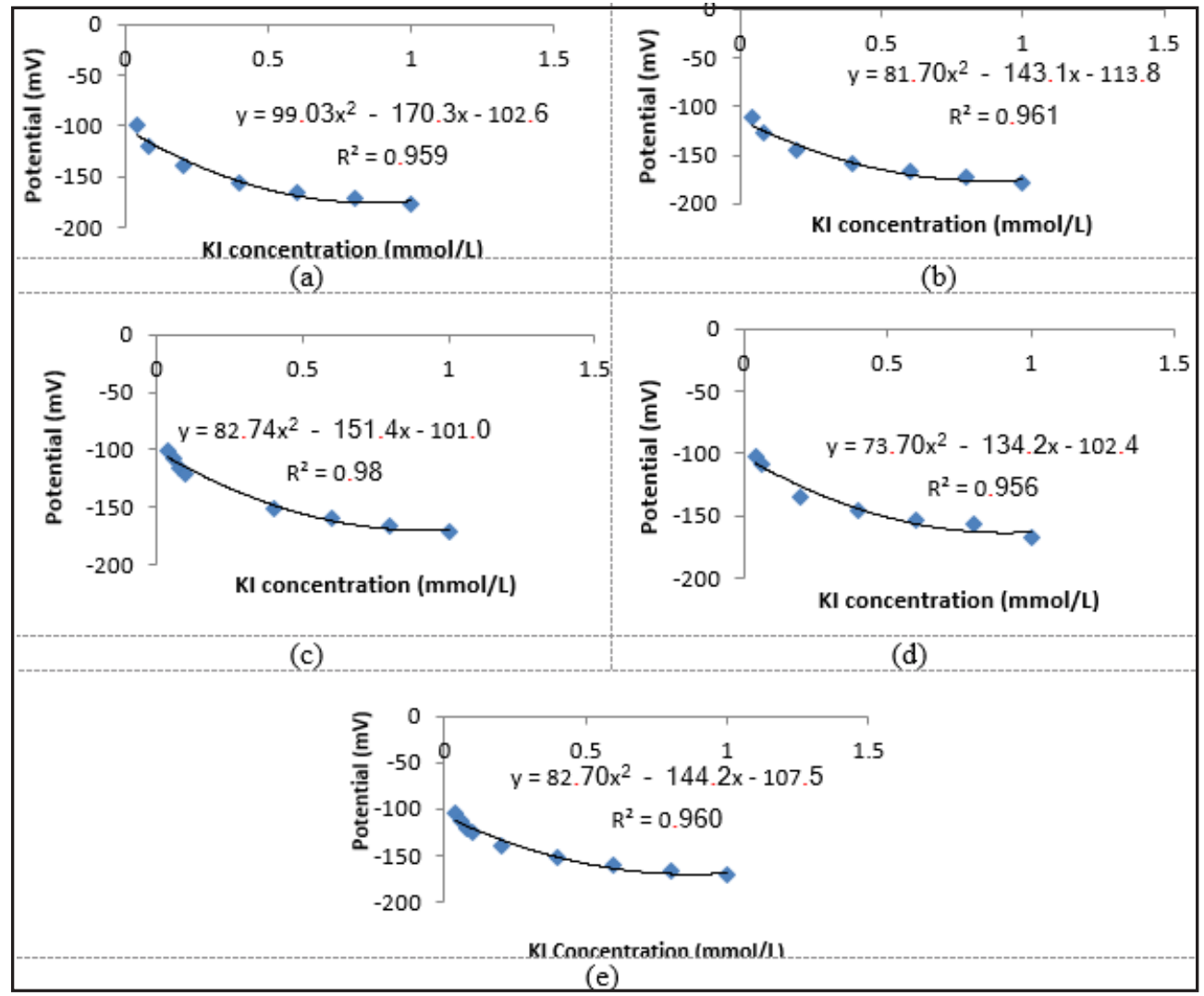

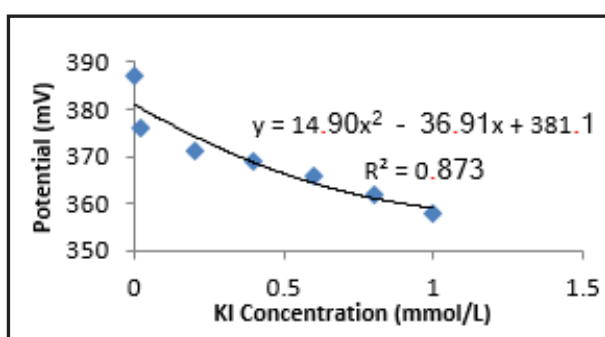

(a)

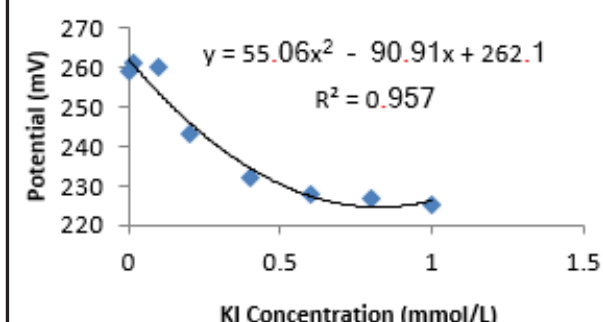

(c)

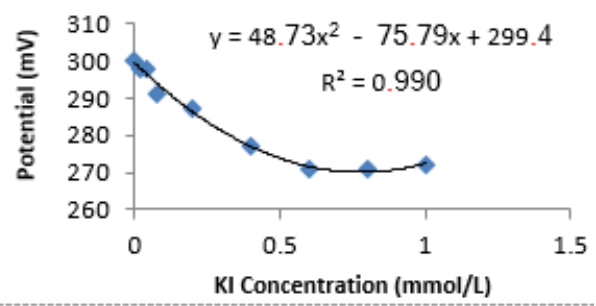

(b)

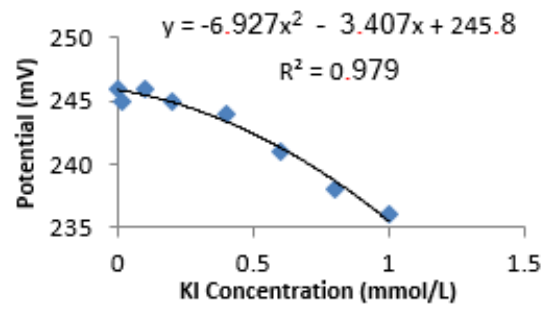

(d)

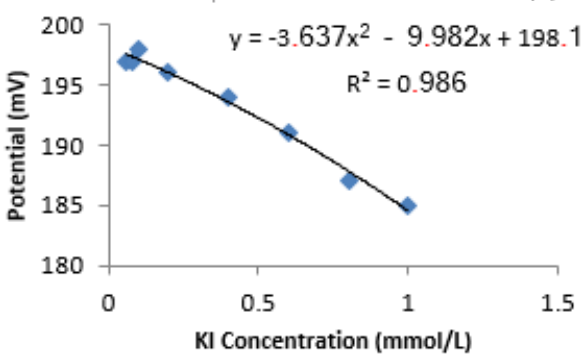

(e)

In this exergonic equilibrium, iodide is viewed as a Lew is base, and the iodine is a Lewis acid.

The lower concentration of KI that was detected using all these electrochemical methods was between 20-100 $\mu \mathrm{mol} / \mathrm{L}$. The difference between DPV and CV methods were regarding the sensor reactivity in buffer, depending on $\mathrm{pH}$ values. For each condition was indicated the best calibration curve as linear or polynomial dependencies. The sensitivities of each method are determined by the slope of the dependence between signal and the sample

concentration. To calculate the slopes of the polynomial curves, the first degree derivation of the mathematical function was used and the slope value was obtained by equating the function to zero [29].

$$
f(x)=a x^{2}+b x+c \quad a \neq 0 \text { and } a, b, c \in \mathbb{R}
$$

$$
\begin{aligned}
& f^{\prime}(x)=2 a x+b \\
& f^{\prime}(x)=0 \\
& x=-b / 2 a
\end{aligned}
$$

REV.CHIM.(Bucharest) 70 No. 3 • 2019 
Between the two types of electrochemical methods there are differences in term of registered parameters. Jenco portable microsensors can only determine one parameter for each testing, which is the potential or the $\mathrm{pH}$, and they have the advantage of reduced time of testing (about $30 \mathrm{~s}$ ) if the electrode is stabilised. Using screenprinted carbon electrodes a wide range of parameters can be obtained: the height of the peak, area, potential, width and also it can be observed the presence of other electroactive substances from the testing solution as supplementary peaks, thereupon the time of testing is prolonged- 6 min for DPV method and $3 \mathrm{~min}$ for CV. Also, the results of the experiments from J enco portable meter indicate the measurements as digital values (potential or $\mathrm{pH}$ ), whereas using PalmSens system with screen printed carbon electrodes are obtained graphic representation of peaks from each substance which contribute to the redox process.

Even if using silver working electrodes could be obtained low limit of detection [30], the electrodes need to be replaced because of the formation of silver iodide (AgI) as precipitate on the surface of the working electrode. Using expensive platinum (Pt) or gold ( $\mathrm{Au}$ ) working electrodes, the detection of iodide is possible for concentrations greater than or equal to $1 \mathrm{mM}$ due also to the surface passivation of the electrode [31,32]. In our experiments, carbon electrodes were used. Carbon electrodes (glassy carbon, pyrolytic carbon fibres) are used successfully for iodide detection because of their stability, lower costs and the possibility to be easily modified for sensitive detection of iodide [33].

From the results showed above is deducted that by the two types of electrochemical methods using screenprinted carbon electrodes (DPV and CV) and Jenco microelectrodes (for iodide detection), iodide can be easily determined qualitatively and quantitatively. Both methods are safe and easy to use, and can be thought of as a portable system with a wide range of applicability [34-40] (screen electrodes are already used to detect toxic and bioactive compounds in the life sciences), alongside other validated methods for the same purpose [41-47]. Redox microelectrodes correlate in a good manner the redox status of the solution with $\mathrm{KI}$ concentration.

\section{Conclusions}

These results indicated acceptable interpretative agreement between DPV, CV and J enco methods in each comparison, with a lower detection between 20-100 $\mathrm{mmol} / \mathrm{L}$. Nevertheless, the portable micrometer is much easier to use, but does not provide too many information about the tested compound, is limited to potential, $\mathrm{pH}$ and, for some apparatus, also temperature. Screen-printed electrodes are more advantageous for quantitative determination and by now have proven a broad applicability. The results showed in this paper have as consequence the wide applicability in testing different solution and also fluids from patients (urine, saliva, blood), in order to determine the concentration of iodine for different patients, following the pattern obtained in those experiments.

\section{References}

1.D'ULVIO, A., PAGLIAN, E., ONOR, M., PIZALIS, E., ZAMBONI, R., Anal. Chem., 81, 2009, p. 6399.

2.KASPER, D., FAUCI, A., HAUSER, S., LONGO, D., JAMESON, J.L., LOSCALZO, J., Harrison's principles of internal medicine, $14^{\text {th }} \mathrm{Ed}$., Volume II, p. 2212.

3.TAYLOR, P.N., OKOSIEME, O.E., DAYAN, C.M., LAZARUS, J.H., Eur. J. Endocrinol., 170, no. 1, 2013, p. R1.
4.VANDERPAS, J.B., MORENO-REYES, R., Minerva Med., 108, no. 2, 2017, p. 124.

5.SANTOS-OLIVEIRA, R., SMITH, S.W., CARNEIRO-LEAO, A.M.A., An. Acad. Bras. Cienc., 80, no. 4, 2008, p. 665.

6.MESKO, M.F., MELLO, P.A., BIZZI, C.A., DRESSLER, V.L., KNAPP, G., FLORES, E.M.M., Anal. Bioanal. Chem., 398, 2010, p. 1125.

7.WORLD HEALTH ORGANIZATION, Assessment of iodine disease disorders and monitoring their elimination, Geneva, 2007.

8.FIERRO, S., COMNINELLIS, C., EINAGA, Y., Simultaneous detection of iodine and iodide on boron doped diamond electrodes, Elsevier B.V., 2012.

9.DIELACHER, B., TIEFENAUER, R.F., JUNESCH, J., VOROS, J. Nanotechnol., 26, 2015, p. 02520.

10.CIFTCI, H., TAMER, U., Anal. Chim. Acta., 687, no. 2, 2011, p. 137. 11.RADOVICl, O., BADEA, G.E., BADEA, T., Rev. Roum. Chim. 48, 2003, p. 591.

12.BADEA, G.E., BADEA, T., Rev. Roum. Chim., 49, 2004, p. 855.

13.BADEA, G.E., BADEA, T., Rev. Roum. Chim., 49, 2004, p. 623.

14.SHI, H., OH-SHIN, Y., KIM, J., RYU, J., J. Chromatogr. A, 732, 1996, p. 327.

15.J OERIN, M., Analyst, 100, 1975, p. 7.

16.WU, D., DENG, H., WANG, W., XIAO, H., Anal. Chim. Acta, 601, 2007, p. 183.

17.JUDPRASONG, K., JONGJAITHET, N., CHAVASIT, V., Food Chem., 193, 2016, p. 2.

18.VARGA, I., Microchem. J., 85, 2007, p. 127.

19.CRECELIUS, E.A., Anal. Chem., 47, 1975, p. 2034.

20.NAOZUKA, J., VEIGA, M.A.M.S., OLIVEIRA, P.V., OLIVEIRA, E., J. Anal. At. Spectrom., 18, 2003, p. 917.

21.RADLINGER, G., HEUMANN, K.G., Anal. Chem., 70, 1998, p. 2221.

22.GELINAS, Y., IYENGAR, G.V., BARNES, R.M., Fresenius J . Anal. Chem., 362, 1998, p. 483.

23.KANPP, G., MAICHIN, B., FECHER, P., HASSE, S., SCHRAMEL, P., Fresenius J. Anal. Chem., 362, 1998, p. 508.

24.GELINAS, Y., KRUSHEVSKA, A., BARNES, R.M., Anal. Chem., 70, 1998, p. 1021.

25.SCHRAMEL, P., HASSE, S., Mikrochim. Acta, 116, 1994, p.. 205.

26.NOBREGA, J.A., GELINAS, Y., KRUSHEVSKA, A., BARNES, R.M., J. Anal. At. Spectrom., 12, 1997, p. 1243.

27.FECHER, P.A., GOLDMANN, I., NAGENGAST, A., J . Anal. At. Spectrom., 13, 1998, p. 977.

28.CHO, E., PEREBIKOVSKY, A., BENICE, O., HOLMBERG, S., MADOU, M., GHAZINEJAD, M., Sensors (Basel), 18, no. 5, 2018, p. 1486.

29.***, http://www.campusgate.co.in/2012/10/slope-of-polynomial.html accessed 10.07.2018.

30.CATALDI, T.R.I., RUBINO, A., LAVIOLA, M.C., CIRIELLO, R., J. Chromatogr. B. 827, 2005, p. 224.

31.TOH, H.S., TSCHULIK, K., BATCHELOR-MCAULEY, C., COMPTON, R.G., Analyst, 139, 2014, p. 3986.

32.DIELACHER, B., TIEFENAUER, R.F., JUNESCH, J., VOROS, J., Nanotechnol., 26, 2015, p. 025202.

33.LOWE, E.R., BANKS, C.E., COMPTON, R.G., Electroanalysis., 17, 2005, p. 1627.

34.BADEA, M., CHIPEREA, C., BALAN, M., FLOROIAN, L., RESTANI, P., MARTY, J.-L., IOVAN, C., TIT D. M., BUNGAU, S., TAUS, N., Farmacia, 66, no. 1,2017, p. 83.

35.BADEA, M., FLOROIAN, L., RESTANI, P., COBZAC, S.C., MOGA, M., PLoS One., 11, no.7, 2016, p. e0160021.

36.BADEA, M., FLOROIAN, L., RESTANI, P., MOGA, M., Int. J . Electrochem. Sci., 11, 2016, p. 6719.

37.BADEA, M., IDOMIR, M., TAUS, N., POPESCU, C., SCORTEA, R., COMAN, G., NUNES G.S., MARTY J.L., J. Environ. Prot. Ecol., 9, no. 1, 2018, p. 33.

38.BUNGAU, S., BALDEA, I., COPOLOVICI, L., Rev. Chim.(Bucharest), 54, no. 3, 2003, p. 213.

39.BUNGAU, S., TIT, D. M., IOVAN, C., COPOLOVICl, L., BOSCENCU, R., CIOCA, G., COPOLOVICI, D., Rev. Chim.(Bucharest), 68, no. 11, 2017, p. 2495. 
40.MICCOLI, A., RESTANI, P., FLOROIAN, L., TAUS, N., BADEA, M. CIOCA, G., BUNGAU S., Rev. Chim.(Bucharest), 69, no. 4, 2018, p. 854. 41.CIOCA, G., BACAITA, E.S., AGOP, M., URSULESCU LUPASCU, C., Comput. Math. Meth. Med., 2017, 2017, doi: 10.1155/2017/5748273

42.MOISA, C., COPOLOVICI, L., BUNGAU, S., POP, G., IMBREA, I., LUPITU, A., NEMETH, S., COPOLOVICI, D., Farmacia, 66, no. 2, 2018, p. 289.

43.MOROSINI, C., MARSONI, M., TORRETTA, V., CONTI, F., RAGAZZI, M., RADA, E., CIOCA, G., Sustainability, 9, no. 8, 2017, doi: 10.3390/ su9081466.

44.MOSTEANU, D., BARSAN, G., GIURGIU, L., EPURE G., Rev. Chim.(Bucharest), 60, no. 3, 2009, p. 290.
45.MOSTEANU, D., BARSAN, G., OTRISAL, P ., GIURGIU, L ., OANCEA, R., Rev. Chim.(Bucharest), 68, no. 11, 2017, p. 2499.

46.MOT, C.A., LUPITU, A.I., BUNGAU, S., COPOLOVICI, D.M., PURZA, L., MELINTE (FRUNZULICA), C.E., COPOLOVICI, L., Rev. Chim.(Bucharest), 69, no. 5, 2018; p. 1041

47.PETREA, N., GINGHINA, R., PRETORIAN, A., PETRE, R., BARSAN, G., OTRISAL, P., MOSTEANU, D.E., Rev. Chim.(Bucharest), 69, no. 7, 2018, p. 1640.

$\overline{\text { Manuscript received: } 29.07 .2018}$ 